\title{
Article
}

\section{Teaching midwives homeopathy-A Belgian pilot project}

Lombaerts, Christel and Vanthuyne, Hilde

Available at http://clok.uclan.ac.uk/23204/

Lombaerts, Christel ORCID: 0000-0001-7112-4017 and Vanthuyne, Hilde (2018) Teaching midwives homeopathy - A Belgian pilot project. European Journal of Integrative Medicine, 21 . pp. 16-23. ISSN 1876-3820

It is advisable to refer to the publisher's version if you intend to cite from the work. http://dx.doi.org/10.1016/j.eujim.2018.05.013

For more information about UCLan's research in this area go to http://www.uclan.ac.uk/researchgroups/ and search for < name of research Group>.

For information about Research generally at UCLan please go to http://www.uclan.ac.uk/research/

All outputs in CLoK are protected by Intellectual Property Rights law, including Copyright law. Copyright, IPR and Moral Rights for the works on this site are retained by the individual authors and/or other copyright owners. Terms and conditions for use of this material are defined in the policies page.

\section{CLoK}

Central Lancashire online Knowledge www.clok.uclan.ac.uk 


\section{Author information}

Christel Lombaerts (Lombaerts, C.)

Centrum voor Klassieke Homeopathie, Belgium

- christellombaerts@gmail.com

- Corresponding author at: Centrum voor Klassieke Homeopathie, Lintsesteenweg 66, B-2540 Hove, Belgium; mobile 32475596554

Hilde Vanthuyne (Vanthuyne, H.)

Centrum voor Klassieke Homeopathie, Belgium

Ravenstraat 51, 3000 Leuven

hilde vanthuyne@hotmail.com

Both authors are independent guest lecturers at Thomas More College, Lier (Belgium) and Centrum voor Klassieke Homeopathie, Belgium. 


\title{
Authors:
}

Christel Lombaerts, MSc Education Sciences, MSc Homeopathy, RHom

Hilde Vanthuyne, MSc Pedagogy, RHom

\begin{abstract}
Introduction

Recent Belgian legislation generated the need for homeopathic training of midwives. The Centre of Classical Homeopathy (CKH) offered a 50-hours course in homeopathy as a pilot project within the Continuing Professional Development (CPD) program of Thomas More College.
\end{abstract}

\section{Methods}

The curriculum was designed to combine a minimum of homeopathic philosophical underpinning with appropriate clinical exercises within the limited training hours available. Eight participants followed the course. Evaluation of the course followed in the last session through a self-completed questionnaire with closed questions on course content and transfer to practice and open questions on didactics and the organisation of the course. Recommendations for the future were also queried.

\section{Results}

Although the learning objectives were met, participants provided useful feedback regarding content and method for the future organisation of the course. They felt more topics should be treated, such as the postpartum period. They suggested supplementing the material from the current training with more practice and cases, and expanding the course to a full year's training, allowing more time between sessions for processing the material. To use homeopathy for acute prescribing, more training on repertorisation techniques and materia medica knowledge would be required.

\section{Conclusions}

Training midwives in homeopathy requires considerably more time than the 50 contact hours stipulated by law and would best be offered as interactive sessions providing powerful concrete case examples, spread over the course of one full year to allow for integration of the material into practice.

Keywords: homeopathy, midwifery, education, Belgium, training

\section{Introduction}

Since 2014 Belgian law has allowed midwives to practise homeopathy provided they take a 50 hours theoretical course and 50 hours of clinical training in an obstetric practice. To date no official educational organisation has included this training in a midwifery education program. The Belgian Centre of Classical Homeopathy $(\mathrm{CKH})$ has been organising professional training in classical homeopathy for medically qualified and non-medically qualified (future) healthcare professionals in line with the education guidelines of the European Central Council of Homeopaths (ECCH) since 1991. The CKH was given the opportunity to provide the legal 50 hours' training in homeopathy for midwives within Thomas More College's (TMC) continuing professional development (CPD) program, called MoreCare. Logistic and administrative support was offered by TMC. The expertise in homeopathy education was delivered by teachers from the $\mathrm{CKH}$.

Homeopathy

Prevalence of homeopathic treatment in Belgium was investigated by the Centre of Expertise (KCE) as part of a Health Technology Assessment (HTA), commissioned by the Belgian Federal Ministry of Health. In a telephone survey the KCE questioned a representative sample of 2000 members of the 
population. Of 1612 respondents, who reported at least one medical condition in the 12 months prior to the survey, $5,6 \%$ of the Belgian population reported having consulted a homeopath in that period; 75\% from them several times in 12 months prior to the survey [1]. This is in line with the average prevalence of homeopathic treatment in Europe but less than the reported use in Switzerland where homeopathy is covered the mandatory health insurance [2].

Clinical and cost-effectiveness are main criteria in the assessment of a medical treatment. Chaufferin [3] calculated that the price of homeopathic products comes down to a quarter of the average amount of reimbursed medical products and the amount reimbursed for homeopathic consultations on only half of those of mainstream general practitioners. Bornhöft \& Matthiessen [4] concluded in their HTA report on Swiss research that homeopathy is clinical- and cost-effective. In Belgium, Van Wassenhoven and Ives [5] found in a Belgian research that in 782 patients treated with homeopathy, complaints improved significantly at a significantly lower treatment cost than with conventional treatment. In 2014, in a literature review, Viksveen [6] found 8 of 14 studies showing costeffectiveness of homeopathic treatment. However, due to the heterogeneity of the selected studies and methodological limitations, no firm conclusions could be drawn from this review. A French nationwide representative survey of General Practices found additional homeopathic treatment for upper respiratory tract infections and musculoskeletal disorders was clinical- and cost-efficient [7].

Despite these findings homeopathy remains a controversial treatment today because of its use of highly diluted substances. Research of homeopathy is hindered by its core tenets regarding individualisation and holism that complicate a research design with RCT's [8]. Nevertheless, several hypotheses have been formulated to explain the working mechanisms of homeopathic remedies, based on principles of system-, quantum- and chaos theories [9] and current research is focusing on the principles of nanoparticles [10]. Meta-analyses have shown some positive evidence for the effectiveness of homeopathy that cannot be completely attributed to the placebo effect. [11-16] However, the effect was found in more of the lower quality studies than in the higher quality studies.

Meanwhile homeopathy has been integrated in the national healthcare systems of Germany, Switzerland and Portugal and has been regulated in Belgium since May 2014.

\section{Homeopathy in obstetric practice}

Midwifery is a special case in homeopathy. For a start, not one, but two persons are treated: mother and foetus, or mother and new-born, or the couple that struggles to get pregnant. Therefore, it is important to distinguish between the various ways in which homeopathy could be used safely and effectively, and to work within those boundaries [17].

Problematically, research undertaken on the evidence for homeopathy in obstetric practice is scarce [18] or is reported as part of wider research on Complementary and Alternative Medicine (CAM) [19]. Adams et al [20] elicited in a literature review of 24 papers, among which 2 on homeopathy, four research gaps in CAM research in obstetric practice: a lack of: large representative samples; indepth understanding of user experiences and risk perceptions; research comparing consumption patterns across cultures and over time; and work exploring the nature of the therapeutic encounter with complementary practitioners in this area of women's health care.

According to a recent review of complementary therapies in obstetric practice undertaken by the workgroup Scientific Research of the Flemish professional society of midwives (VBOV), some added value can be attributed to homeopathic treatment for menstruation and fertility problems. However, 
no clear effect of homeopathic treatment beyond placebo in pregnancy, labour or postpartum was found in the few studies that were available [21]. Equally, a recently published literature review [22] on the safety and efficacy of homeopathy during pregnancy identified Caulophyllum, Actaea racemosa, Arnica montana and China rubra as the most commonly used remedies in pregnancy, during labour and postpartum period. However, due to a lack of good quality evidence, the use of homeopathy during pregnancy and labour could not be supported. However, according to a survey of 1835 Australian women reported in 2015 [23], women who use homeopathy in pregnancy (13,3\% of the total sample) are concerned more about their own personal experience, rather than in the clinical evidence of efficacy. Kalder et al. found [24] that the advice of therapists (especially midwives) and prior positive experiences with CAM are the main reasons for using CAM during pregnancy. Analysis of data from the Avon Longitudinal Study of Parents and Children (ALSPAC) by Bishop et al. [25] confirms the frequent use of homeopathy (14,4\% of a pregnancy sample of 14,115 women, with Arnica as the most frequently used homeopathic remedy, suggesting that women are using CAM as part of a self-care approach. Mitchell [26] presented some findings in an empirical qualitative research with 14 women of which 2 used homeopathy during pregnancy. The data presented suggest that CAM use has a positive transformational effect on women's experience of pregnancy and childbirth. Nevertheless, homeopathy is the third most recommended complementary therapy according to a survey conducted in 2014 in a Scottish maternity service [27]. In another literature review investigating midwives' support for CAM-therapies internationally, homeopathy is also included as one of many complementary treatments supported in obstetric practice. However results diverge widely, homeopathy's popularity varying from least to most popular [28]. Moreover, support for complementary therapies among midwives does not automatically include support for homeopathic treatment which is thought to require advanced skills [29]. Specialist literature on this topic is limited.. The few available textbooks typically will advise on interventions in pre- and postnatal care, alleviation of non-life threatening but distressing ailments during delivery, supporting breastfeeding, and alleviation of non-life threatening but taxing complaints of the new-born in the first months [30,31]. Moreover, homeopaths have developed treatment programs in supporting couples with infertility problems [32]. Kalampokas et al. [33] describe five case studies of successful homeopathic treatment of infertility.

There is some positive research focusing on homeopathic treatment in obstetric practice.. In a randomized, double-blind, placebo-controlled study, Oberbaum et al [34] found that treatment with homeopathic Arnica montana and Bellis perennis may reduce postpartum blood loss, as compared with placebo.

Overall, limited evidence suggests that homeopathy may contribute positively to well-being during pregnancy and the process of natural childbirth. A number of complaints during and after pregnancy are closely linked to the mental-emotional condition of the woman. Since the homeopathic remedy is presumed to influence mental-emotional as well as physical aspects of the pregnant woman, a wellconsidered and competent prescription in an early stage could prevent an escalation of certain problematic situations [35].

Indeed, in obstetric practice, a normal and healthy condition can suddenly and quickly turn into a problematic one due to heightened sensitivity and vulnerability. Therefore, at all times a 
conscientious and frequent monitoring by a licensed midwife is of the utmost importance. Despite this rather acute aspect of midwifery, the individual context and specific concomitant symptoms of every case should be considered within the framework of a homeopathic treatment. Midwives have an edge in doing this because they have already been thoroughly trained in observation and anamnesis [36].

Midwives are found to be often motivated to practice homeopathy by personal or family health issues [27,37], or because they felt it was congruent with their philosophy [37,38]. Nevertheless, practising homeopathy, just as any CAM practice, needs extra patience, time and energy [39]. Often the energy involved for the treatment to be accepted is so consuming, that midwives leave public health service and start private CAM practices [40]. Equally Duckworth found that studying homeopathy is adding to the authenticity of the midwife, eventually forcing her to leave a mainstream medical context [37].

Regarding education in CAM, Tiran [41] warns about the risks attached to CAM use in obstetric practice due to a lack of knowledge both in midwives and gynaecologists. For instance, confusion between herbal and homeopathic remedies was a concern. Cant, Watts, \& Ruston [40] write that midwives are responsible for their own education in CAM but authorities do not specify what competencies are involved. Midwives find this lack of prescription troublesome as it leaves them dependent on informal advice as to which training courses to undertake and where to register. This is where the decree for regulating the practice of homeopathy in Belgium comes in.

\section{Methods}

Design of the course

In the decree regulating the practice of homeopathy, 50 hours on theory and 50 hours of clinical training is set as a minimum for the training of midwives who want to register as a homeopath. Literature on training on homeopathy specifically in obstetric practice is scarce and often included in general research on training in CAM practice [39].

Existing homeopathy training for midwives organised in Belgium often comes down to a private initiative of medical homeopaths offering a two-day weekend course on 'practical' homeopathy. Homeopathy short courses are organised on a regular basis by the Centre d'Enseignement et de Developpement de l'Homéopathie [CEDH], the educational department of manufacturer of homeopathic remedies Boiron [42]. These two-day courses are clinically oriented and treat the use of homeopathic complex medicine in obstetric practice. Complex remedies contain a mixture of homeopathic remedies in one dose, targeting minor or acute problems, in contrast with individualised treatment with one dose of a single remedy, referred to as classical homeopathy. However in the spirit of the Belgian decree the training should encompass classical homeopathic philosophy and be organised in an officially accredited college or university [43]. In fact, the practice of classical homeopathy requires a more lengthy training, differing from the much simpler acute prescribing or self-administration [44]. Indeed, a standard curriculum of a full training in homeopathy covers $450-500$ contact hours and about 7 times as much study hours. A large part of this time is devoted to assimilate and adopt the homeopathic paradigm and revolutionise one's thinking that normally underpins the conventionally trained (para)medic's decisions. The tension caused on the one hand by the legally compulsory but limited duration of the course and the strongly dissimilar decision process on the other, has largely informed content and form of the trajectory in the pilot project. To overcome this tension, deep learning had to be fostered, adding to the challenges in 
designing the course, since the literature points at medical students' tendency to focus rather on knowledge intake [45]. However, on a positive note, midwives have already acquired professional consultation skills in their midwifery training and practice [36].

Taking this context into account, a curriculum was designed steeped in constructivist theory and fostering transformative learning [46]. Starting from the course context and characteristics of the participants and aiming at a minimum outcome the following learning objectives were formulated to assist the teachers' team in selecting course content:

1. The student gets in touch with the homeopathic/holistic philosophy and leaves the notion of 'prescribing something for or against a medical condition'.

2. The student starts to let go of exploring psychological or biomedical causal relationships and rather accepts 'what is'.

3. The student learns to respect the individual characteristics of the pregnant woman and the baby and uses these as a basis for a prescription, at the same time - temporarily - letting go of conventional medical labels and protocols.

4. In homeopathic treatment of a case, the student takes into account the totality as well as the essence of the remedy to be selected.

5. The student knows where and how to find literature on homeopathy.

The first three objectives highlight the thresholds conventionally trained medical professionals may encounter when integrating the homeopathic paradigm. For the students' evaluation, the learning objectives were formulated more positively.

The focus of the course was put on the introduction of the homeopathic philosophy and the skills to find information and independently gain knowledge. The program was divided in two parts; the first (22 hours) concentrating on gaining insight in the homeopathic paradigm and the second ( 28 hours) aiming at its application in obstetric practice with delimited instruction in materia medica and obstetric case-taking.

\section{Course content and delivery}

In order to promote deep learning, an approach combining didactics and experiential learning [47] provided space for the participants' own casuistic work [48]. Participants, all licensed midwives, possibly would have some previous knowledge on homeopathy. Therefore, during the first day of the course, ample opportunities had to be incorporated for feedback on previously acquired knowledge and skills, to remove eventual barriers to learning [49]. The first three course days the holistic aspect, homeopathic sources and the homeopathic conversation were discussed. The following three course days covered homeopathic support during pregnancy, homeopathic interventions during labour and homeopathic support for breastfeeding and during the first stage of life of the new-born. On the last course day infertility problems were discussed. The total of seven course days was spread over four months.

The choice of topics (pregnancy, labour, breastfeeding and the first stage of life, fertility) was based on results of inquiries with last year midwifery students at the TMC at the end of a three-hour introduction session on homeopathy which is part of a module in the minor program in their midwifery education. The topic of each course day was consigned to the teacher best qualified and most experienced on the matter to assure that all learning content was delivered with maximum expertise. The eventual disadvantages of dispersing the learning content over different teachers were circumvented by recording the lessons and making the recordings available for all teachers in 
the team. The topics on the practice-oriented days were illustrated by cases and the remedies explained through differentiation, a tested didactic/learning method [50].

The maximum group size was set at 15 participants to allow for interactive sessions. A reading list with seminal works on homeopathic philosophy, theory and materia medica was provided, listing general information on homeopathy as well as information on homeopathy in obstetrics in particular.

In order to enable time spent on appropriate exercises and practice, the materia medica lessons on 25 specific remedies were delivered by 30 minutes video clips, presenting the absolute minimal insight in each specific remedy. Eighteen remedies ${ }^{1}$ were selected from - the most appropriate remedies in repertorising, i.e. using a list of symptoms of typical complaints occurring in pregnancy, during labour and postpartum, to identify the most common homeopathic remedies for these conditions; ; - remedies described in homeopathic obstetric literature; -remedies included in a homeopathic pregnancy kit. Seven more remedies ${ }^{2}$ were suggested by teachers who wanted to present them as case examples.

PowerPoint presentations, exercises, textbooks and other learning materials were shared with the participants after each session.

\section{Clinical training}

As there did not exist an obstetric practice registered by Belgian law at the time of the course, the legal requirements for the clinical training could not be met. Therefore, clinical training was to take place in the midwife's own obstetric practice under supervision of a homeopath, or in the practice of a homeopathic medical doctor, who would take the obstetric case in the presence of the midwifetrainee.

\section{Evaluation of the learning process}

Assessment is a powerful tool to influence learning strategies [51]. To foster deep learning, instead of probing for knowledge acquired, participants were prompted to reflect on their learning process [52]. Participants were asked to write maximum three pages, taking a case from their conventional obstetric practice. They should describe shortly how, previously to the course, they were thinking through that case; what considerations led them to the treatment they decided upon; and how they evaluated their treatment at the time. Next they were asked to describe how they would now approach the same case from a homeopathic perspective. How would that change their thinking? What observations or information would lead to a decision on a possible homeopathic prescription and how would this differ from their earlier approach? They were asked to discuss their proposed prescription based on information from the homeopathic literature.

For the evaluation of this paper, the learning objectives were weighed and communicated as follows:

1. The student gets insight in the homeopathic/holistic philosophy: 3 points.

2. The student accepts 'what is': 2 points.

3. The student respects the individual characteristics of the pregnant woman and the baby and uses these as a basis for a prescription: 3 points.

\footnotetext{
${ }^{1}$ Apis, Arnica, Arsenicum, Belladonna, Bellis Perennis, Caulophyllum, Chamomilla, Cimicifuga, Kalium Carbonicum, Lacticum Acidum, Phosphorus, Phytolacca, Podophyllum, Pulsatilla, Secale, Sepia, Staphisagria, Veratrum Album.

${ }^{2}$ Aconitum, Carbo Veg, Calcarea, Colocynthis, Ipeca, Aurum, Lycopodium
} 
4. In homeopathic treatment of a case, the student takes into account the totality as well as the essence of the remedy to be selected: 1 point.

5. The student knows where and how to find literature on homeopathy: 1 point.

\section{Evaluation of the course}

On the last day of the course, participants were asked to complete an anonymous paper questionnaire (Appendix A) with partly closed and partly open questions. The quality of the training was evaluated on four elements: content, transfer to practice, didactics and, for practical purposes only, the organisation of the training. Recommendations to optimize the training were queried. The questions were formulated after discussion and review between researchers. An explanatory mixed method was used for analysing the data, allowing for the results to be reported as a narrative document [53]. The drafting of the questionnaire as well as the analysis of the data and reporting of the results was initiated by one researcher and reviewed by the other.

The questions on content and transfer to practice were scaled from 1 (negative) tot 5 (positive). The quantitative data were analysed and summarised with Excel. The open questions on content, transfer, didactics and organisation of the training provided qualitative data clarifying and completing the quantitative data. The scarcity of qualitative data did not call for multiple rounds of coding and interpreting. Qualitative data were manually analysed, using summative content analysis. Content analysis differs from thematic analysis in that themes are latent information derived from categories which constitute manifest information. [53]. A summative content analysis involves counting and comparisons, usually of keywords or content, as described by Hsieh and Shannon [54]. A framework (Appendix B) with a summary of the raw data, showing participants' answers in rows for each category in the corresponding column [55], allows for counting and eliciting latent themes. Quantitative and qualitative results were reported in a summarising narrative text document

\section{Selection of the participants}

In Flanders, about 700 midwives are registered with the professional society VBOV. A minority of these are independently working midwives. Midwives interested in CAM therapies have set themselves up in small support groups, independent from the VBOV. No data are available about the size and working of these groups.

The course was advertised on the VBOV's website, the CKH's website and on TCM's webpage on CPD. Participants would register through the online registration program of TMC.

The course was submitted for accreditation to the VBOV, who has the authority to license the course with the federal authorities for education in healthcare. Accreditation was granted in May 2015. The course was organised according the regulations for CPD of Thomas More College. The evaluation form used was passed to the person responsible for the CPD courses of the MoreCare programme, who distributed the form at the last day of the course.

Ethical approval was not required, since the research aimed at an evaluation of content, transfer, didactics and organisation of the course, within the limited time frame of 50 hours, as legally stipulated. The research was conducted as far as possible within the financial and time constraints according to the Ethical Code for Scientific Research in Belgium established in 2008 by the Koninklijke Academie voor Geneeskunde van België [56] 
The researchers who analysed the data of the evaluation acted independently, and were not accountable to the partnering institutions. They provided the participants with a leaflet containing information on the content and organisation of the course. Participants consented to 1) the course being subject of a research project/article; 2 ) the use of the findings emerging from the questionnaire they completed for this journal article; 3 ) they understood that data and quotes would be made anonymous and unrecognisable. No private or sensitive data were gathered and participants were not part of a vulnerable population.

\section{Results}

Although a minimum of 12 participants was set, the course started with 8 midwives (Table 1). All participants were female. Age ranged from 19 till 55, with an average of 42 years (median: 47,5 years). Experience ranged from 0 to 35 years with an average of 19 years (median: 18,5 years). Seven were independent midwives supporting home births and providing postpartum and breastfeeding support. One participant was a student-midwife.

Table 1 Demographic Characteristics of the participants (gender, age and years of experience), $n=8$

\begin{tabular}{|c|lcc|}
\hline & Gender & age & Years of experience \\
\hline Participant 1 & Female & 43 & 21 \\
Participant 2 & Female & 55 & 33 \\
Participant 3 & Female & 55 & 33 \\
Participant 4 & Female & 52 & 8 \\
Participant 5 & Female & 19 & 0 \\
Participant 6 & Female & 35 & 16 \\
Participant 7 & Female & 28 & 5 \\
Participant 8 & Female & 52 & 35 \\
\hline Average & & $\mathbf{4 2}$ & $\mathbf{1 9}$ \\
\hline Median & & $\mathbf{4 7 , 5}$ & $\mathbf{1 8 , 5}$ \\
\hline
\end{tabular}

Evaluation of the learning process

Seven participants submitted their paper. Four got marked 7/10, one 7,5/10 and two $9 / 10$. One participant, a student-midwife, attended only a few sessions and did not submit a paper.

\section{Evaluation of the course}

For each item first the quantitative data are reported followed by eliciting the main theme and a narrative summary of the qualitative data.

\section{Content}

The course was judged very interesting in general by $7(87,5 \%)$ participants ( 1 missing). The session pregnancy scored least interesting. 


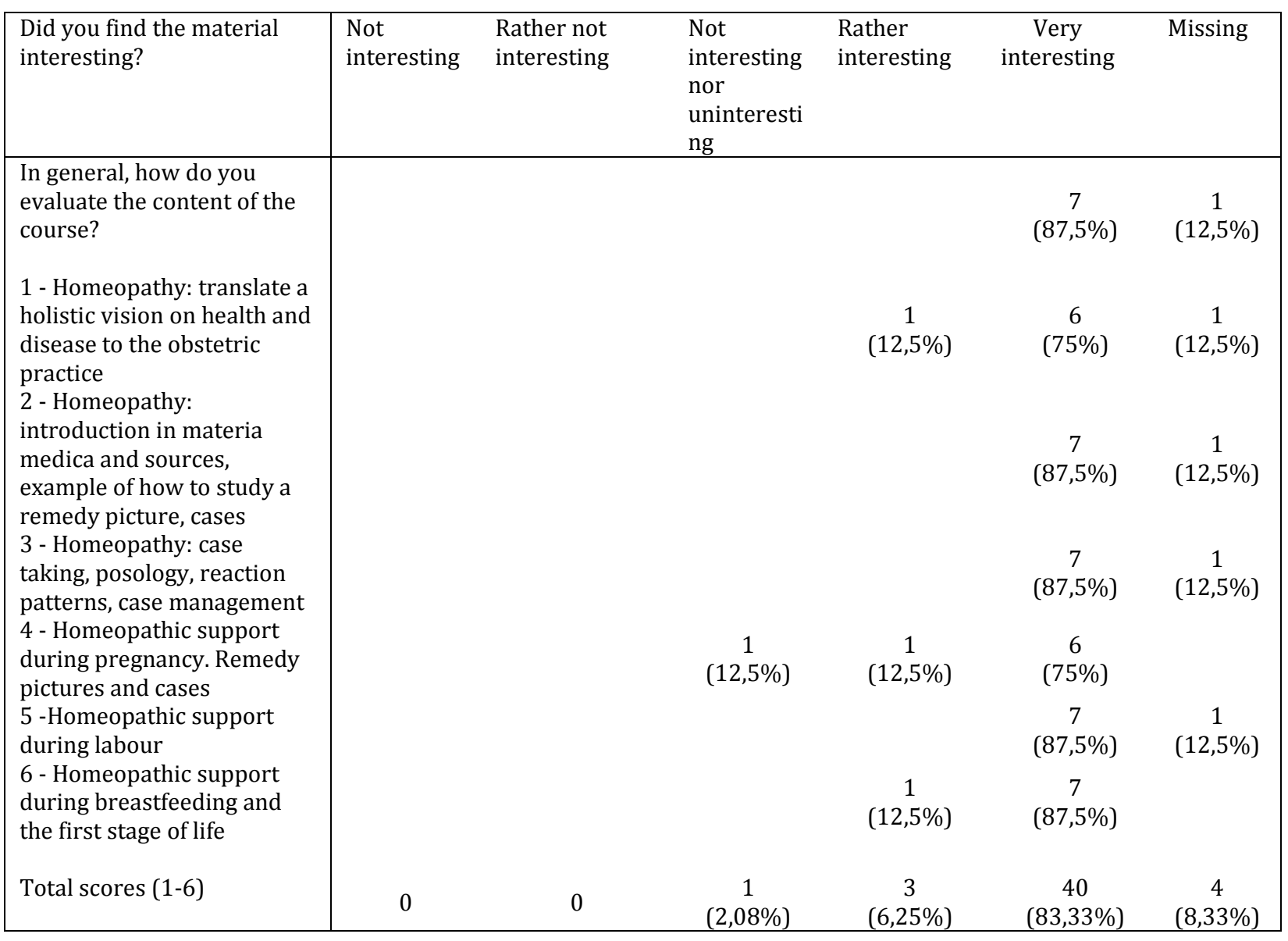

\section{Analysis of the qualitative results on Content}

The following topics were considered most interesting: - the homeopathic vision (resp. A), - how symptoms of the pregnant woman can lead to a prescription for the baby (resp. A), - materia medica grouping the remedies (e.g. according the table of Mendeleev, plant families) (resp. D) , - the cases presented (resp. A, D), and - homeopathic support for breastfeeding (resp. C). However, more help is needed to learn to use the repertory (resp. B) and how to interpret the essence of a case in a homeopathically correct way (resp. B). Equally learning from their own cases and looking for the thread in the case (resp. D) as well as improving case taking skills (resp. B, D) required considerably more time.

In the comments in the open sections on the survey, lack of time to process the information and a lack of practice-linked information come up as the main critiques on the course content.

Table 3 Evaluation of the content of the course; $n=8$; eliciting main themes

\begin{tabular}{|l|l|l|}
\hline Theme A & Lack of practice-linked information \\
\hline Categories & Well-structured in general & $\begin{array}{l}\text { Items lacking or could have been expanded or } \\
\text { presented in more practice-linked way }\end{array}$ \\
\hline Participants & F, G & B, C, D, F \\
\hline Theme B & Lack of time to process information \\
\hline Categories & Overwhelming, lot of information & $\begin{array}{l}\text { Not enough time, too short, insufficient for } \\
\text { practice }\end{array}$ \\
\hline Participants & B,G & B, F, G, H \\
\hline
\end{tabular}




\section{Summary}

The content was generally evaluated positively.

Commenting on this section, four participants reported finding the content of the sessions very interesting and two participants found the course well-structured. One Participant mentioned that despite the short time frame of the course, teachers succeeded in conveying a lot of important information. The sequence in which the content was offered was felt as somewhat overwhelming by two participants, hindering immediate integration of the material. In general participants thought the series was "too short" (resp. F) and felt there remained a hunger for more. For instance, the postpartum period could have been treated more extensively (resp. C).

\section{Transfer to practice}

The quantitative results for transfer to practice varied depending on the topic, but were generally positive; $75 \%$ found the material rather useful or very useful.

Table 4 Transfer to practice, $n=8$

\begin{tabular}{|c|c|c|c|c|c|c|}
\hline $\begin{array}{l}\text { Did you find the material useful } \\
\text { for your obstetric practice? }\end{array}$ & $\begin{array}{l}\text { Not } \\
\text { useful }\end{array}$ & $\begin{array}{l}\text { Rather } \\
\text { not } \\
\text { useful }\end{array}$ & Not sure & Rather useful & $\begin{array}{l}\text { Very } \\
\text { useful }\end{array}$ & Missing \\
\hline $\begin{array}{l}\text { Homeopathy: translate a holistic } \\
\text { vision on health and disease to } \\
\text { the obstetric practice }\end{array}$ & & & & $\begin{array}{c}1 \\
(12,5 \%)\end{array}$ & $\begin{array}{c}6 \\
(75 \%)\end{array}$ & $\begin{array}{c}1 \\
(12,5 \%)\end{array}$ \\
\hline $\begin{array}{l}\text { Homeopathy: introduction in } \\
\text { materia medica and sources, } \\
\text { example of how to study a } \\
\text { remedy picture, cases }\end{array}$ & & & $\begin{array}{c}1 \\
(12,5 \%)\end{array}$ & $\begin{array}{c}2 \\
(25 \%)\end{array}$ & $\begin{array}{c}4 \\
(50 \%)\end{array}$ & $\begin{array}{c}1 \\
(12,5 \%)\end{array}$ \\
\hline $\begin{array}{l}\text { Homeopathy: case taking, } \\
\text { posology, reaction patterns, case } \\
\text { management }\end{array}$ & & & $\begin{array}{c}1 \\
(12,5 \%)\end{array}$ & $\begin{array}{c}2 \\
(25 \%)\end{array}$ & $\begin{array}{c}3 \\
(37,5 \%)\end{array}$ & $\begin{array}{c}2 \\
(25 \%)\end{array}$ \\
\hline $\begin{array}{l}\text { Homeopathic support during } \\
\text { pregnancy. Remedy pictures and } \\
\text { cases }\end{array}$ & & & $\begin{array}{c}3 \\
(37,5 \%)\end{array}$ & $\begin{array}{c}2 \\
(25 \%)\end{array}$ & $\begin{array}{c}3 \\
(37,5 \%)\end{array}$ & \\
\hline $\begin{array}{l}\text { Homeopathic support during } \\
\text { labour }\end{array}$ & & & $\begin{array}{c}1 \\
(12,5 \%)\end{array}$ & $\begin{array}{c}2 \\
(25 \%)\end{array}$ & $\begin{array}{c}4 \\
(50 \%)\end{array}$ & $\begin{array}{c}1 \\
(12,5 \%)\end{array}$ \\
\hline $\begin{array}{l}\text { Homeopathic support during } \\
\text { breastfeeding and the first stage } \\
\text { of life }\end{array}$ & & & $\begin{array}{c}1 \\
(12,5 \%)\end{array}$ & $\begin{array}{c}3 \\
(37,5 \%)\end{array}$ & $\begin{array}{c}4 \\
(50 \%)\end{array}$ & \\
\hline Total scores & & & $\begin{array}{c}7 \\
(14,58 \%) \\
\end{array}$ & $\begin{array}{c}12 \\
(25 \%)\end{array}$ & $\begin{array}{c}24 \\
(50 \%)\end{array}$ & $\begin{array}{c}5 \\
(10,42 \%) \\
\end{array}$ \\
\hline
\end{tabular}

Analysis of the qualitative results on transfer to the obstetric practice

One participant (resp. G) found the material offered in line with her obstetric practice; however all participants felt not ready yet for starting to practice. Participants thought the training was an "introduction" (resp. D) but asked for an extension in order to be confident midwife-homeopaths. Indeed, the limited time frame was seen as a significant barrier. Regular get-together days would be needed to check out each other's' practice or to make case taking exercises (resp. A, E). One participant strikingly claimed 'we've only seen the top of the iceberg...' (resp. F).

Table 5 Evaluation of usefulness of the course; $n=8$; eliciting main themes

\begin{tabular}{|l|l|l|}
\hline Theme A & \multicolumn{3}{|l|}{ Introduction but full homeopathic education required to practice } \\
\hline Categories & More processing time and & Not ready to practice; introduction \\
\hline
\end{tabular}




\begin{tabular}{|l|l|l|}
\hline & training required & \\
\hline Participants & $\mathrm{C}, \mathrm{E}, \mathrm{H}$ & $\mathrm{A}, \mathrm{B}, \mathrm{C}, \mathrm{D}, \mathrm{E}, \mathrm{F}, \mathrm{G}, \mathrm{H}$ \\
\hline
\end{tabular}

\section{Summary}

The general conclusion in this section is that, although the material of each session was considered useful, the course in general was considered an introduction and a full homeopathic training is required to practice confidently as a midwife-homeopath.

\section{Didactics}

According to the participants, teachers succeeded in delivering complex content in a demonstrative and analytical way (resp. A, D, H). However, at times there was a need for more concrete examples (resp. H). Teachers' authenticity in taking a vulnerable position when presenting cases and revealing their own process, was especially appreciated (resp. H). The validity of the cases (real cases from practice) with powerful examples was highly valued (resp. F, H), as they facilitated transfer to practice (resp. G). Finally participants highlighted the importance of interactive sessions (resp. F, G, H). They found it exciting to look for the essential information in a case and appreciated the hermeneutic way (asking helpful questions) in which they were guided through these exercises (resp. A, H).

Table 6 Evaluation of delivery of the course; $n=8$; eliciting main themes

\begin{tabular}{|l|l|l|l|}
\hline Theme A & \multicolumn{3}{|l|}{ Basic principles well explained; more case work needed to facilitate transfer to } \\
practice
\end{tabular}

\section{Summary}

The importance of real case examples and a preference for case work linked to their own practices in interactive sessions came up as a key theme in evaluation the didactics of the course.

\section{Recommendations for the future}

Participants almost unanimously recommended supplementing the material from the current training with more practice and cases, and expanding the course to a full year's training, allowing more time between sessions for processing the material. Also repertorisation techniques should get more attention (resp. D). Most participants claimed that the ideal outcome of the course would be to acquire sufficient knowledge and background enabling them to take a two hours homeopathic consultation on top of their normal routine work (resp. A, B, D, F, H). Some participants thought a complete training as a homeopath would be necessary to reach this level of proficiency (resp. D, F). Other participants, however, would rather use homeopathy for acute prescribing, in which case more training on repertorisation techniques and materia medica knowledge would be required (resp. A, D). One participant (resp. E) would prefer an online course with a coach. 
Table 7 Recommendation for future course; $n=8$; eliciting main themes

\begin{tabular}{|l|l|l|l|}
\hline Theme A & \multicolumn{3}{|l|}{ Short acute course versus full homeopathy education } \\
\hline Categories & $\begin{array}{l}\text { Acute prescribing, quick } \\
\text { repertorisation }\end{array}$ & $\begin{array}{l}\text { Full } \\
\text { training }\end{array}$ & $\begin{array}{l}\text { Start with short course and complement } \\
\text { with deepening }\end{array}$ \\
\hline Participants & D & B, F & A, D, H \\
\hline
\end{tabular}

\section{Summary}

In future, homeopathy education for obstetricians could start with an introduction, training in repertorising and materia medica for acute prescribing, followed by deepening the material with case work and interactive sessions for more proficiency in treating more complex cases. Again the need for more time to deliver and process the material is stressed.

\section{Discussion}

Although a minimum of 12 participants was set, the course started with 8 midwives. Eight participants is a very small group, not representative for the profession as a totality, and not allowing for generalisation of the results. Unfortunately, the number of midwives interested in CAM and specifically in homeopathy is considered to constitute only a small percentage of the registered midwives. Besides, courses organised for medical doctors in Belgium often start with comparable small groups. In this perspective we believe that the project was worthwhile even if the outcomes cannot be generalised.

Following comments by the participants, workshops on prenatal and postpartum homeopathic care were organised in 2016; these workshops were attended by an average of 16 participants. In the beginning of 2017 the 7day's course with accreditation of the VBOV, was repeated, taking into account the comments on the 2015 course, providing homeopathy training to six midwives. The variation in attendance may have several causes worth investigating. A formula with a number of workshop sessions that can be attended separately maybe more appealing to midwives who lead complex professional lives. However, resistance to include CAM training in mainstream education remains problematic to this day and the occasion to organise such a series of workshops in the legal context may have to be postponed until an official document is issued by the government regulating the integration of homeopathy instruction in medical education [57].

In designing the curriculum a TMC teacher in midwifery familiar with homeopathy, a homeopath teaching holistic therapeutics to midwifery students and a midwife-homeopath were asked for suggestions and feedback. However, more attention and time could have been spent on inquiring on the training needs directly with the target group, being independent midwives interested in integrating homeopathy in their practices.

Time and financial constraints did not permit for a more rigorous research design. For practical and cost-efficient reasons, a questionnaire with both open and closed ended questions was used for the evaluation of the course. It is debatable, however, whether this would count as triangulating mixed methodology in the strictest sense, since this was a mono-strand design and the additional information from the unstructured data were analysed in a quantitative way [58]. Participatory action research, using a multi-method approach, for instance with participants keeping a reflective diary, face-to-face interviews or focus groups, and observation during clinical training [59], would yield more information about changes in attitude and transfer of knowledge and skills in practice. 
Equally, time and financial constraints did not permit for long-term evaluation. Transfer to practice has proven to be problematic, amongst others due to some practical issues. After concluding the 7days' training, five of seven graduated participants followed 10 online sessions of summer training and one full day of clinical training, to deepen their insights and understanding on homeopathic philosophy and expand their knowledge on materia medica. Subsequently of these five participants, four registered for the full homeopathy training, for which they got a number of exemptions. As for the clinical training, five of the seven graduated participants are in the process of getting supervision. End of 2017, three participants who are not on the full homeopathy training reported only sporadically using homeopathy in their practice, feeling that they need more clinical training and supervision to feel confident about their treatment.

Whilst 7 days is a short period to deliver a course, compared to a full 5-years program, examples exist of courses abroad that run in a comparable, be it a bit longer, time frame. In the Netherlands, homeopathy in obstetric practice often is the subject of a module that is part of the full training in homeopathy for medically trained healthcare professionals; only recently the Vereniging Verloskunde en Homeopathie started offering an all-embracing modular 20-days' training on a professional bachelors' level [60]. The 'Ausbildungszentrum für Homöopathie in der Frauenheilkunde, Privatklinik Döbling' in Vienna offers a 10-day course covering all aspects of a classical homeopathy education - materia medica, repertorisation, consultation, case analysis and case management [61].

\section{Recommendations for further research}

Follow-up research is recommended to identify the needs for licensed midwives-homeopaths for continuing professional development that would allow them to integrate homeopathy in their practices.

Future research should, if at all possible, focus on a larger group of participants. Following up on the recommendations made by participants, the course design should be adapted to include more case examples from practice and expanded with more topics to cover the full range of obstetric practices. Qualitative evaluation research, using a multi-method approach, for instance with participants keeping a reflective diary, face-to-face interviews or focus groups, and observation during clinical training, in a larger sample, would yield more robust findings.

Research could also focus on other course designs, such as workshop-based courses or online courses, which might balance time and financial constraints with the complexity and richness of homeopathy training.

\section{Conclusion}

Currently universities and colleges in Belgium are opposed to offering homeopathy education as part of the curriculum in midwifery teaching programs. However, public demand for homeopathy and Belgian law has put midwives in a position where they could serve the public with complementary homeopathic treatment in a cost-efficient and safe way, provided they have had an appropriate training on homeopathy. Such training, whether offered as part of the standard curriculum or as a CPD training, would require considerably more time than the 50 contact hours stipulated by law and would best be offered as interactive sessions providing powerful clinical case examples, spread over the course of one full year to allow for integration of the material into practice. Ample attention should be given to repertorisation, case taking and analysis techniques and exercises. Possibly an 
introduction and acute prescribing course could be followed by more in-depth training for those wishing to practice on a more proficient level. Further research into the training needs of midwives regarding homeopathy is required.

Authors: All research done by the authors.

Conflicts of interest: none.

\section{Acknowledgements:}

To Thomas More College, department Continuing Professional Development 'More Care' for Midwifery, Lier (Belgium) who provided vital support in organising this project.

This research did not receive any specific grant from funding agencies in the public, commercial, or not-for-profit sectors. 


\section{References}

[1] T. De Gendt, A. Desomer, M. Goossens, G. Hanquet, C. Leonard, J. Pierart, R. Mertens, J. Robays, D. Roberfroid, O. Schmitz, I. Vinck, L. Kohn, Stand van zaken van de homeopathie in België., Federaal Kenniscentrum voor de Gezondheidszorg, Brussels, 2011. zotero://attachment/185/ (accessed December 22, 2011).

[2] C. Relton, K. Cooper, P. Viksveen, P. Fibert, K. Thomas, Prevalence of homeopathy use by the general population worldwide: a systematic review, Homeopathy. 106 (2017) 69-78. doi:10.1016/j.homp.2017.03.002.

[3] G. Chaufferin, Improving the evaluation of homeopathy: economic considerations and impact on health, Br. Homeopath. J. 89, Supplement 1 (2000) S27-S30. doi:10.1054/homp.1999.0376.

[4] G. Bornhöft, P. Matthiessen, Homeopathy in Healthcare: Effectiveness, Appropriateness, Safety, Costs, EACH, Baden-Baden, 2011..

[5] M. Van Wassenhoven, G. Ives, An observational study of patients receiving homeopathic treatment, Homeopathy. 93 (2004) 3-11. doi:10.1016/j.homp.2003.11.010.

[6] P. Viksveen, Z. Dymitr, S. Simoens, Economic evaluations of homeopathy: a review, Eur. J. Health Econ. 15 (2014) 157-174. doi:10.1007/s10198-013-0462-7.

[7] L. Grimaldi-Bensouda, B. Bégaud, M. Rossignol, B. Avouac, F. Lert, F. Rouillon, J. Bénichou, J. Massol, G. Duru, A.-M. Magnier, L. Abenhaim, D. Guillemot, Management of upper respiratory tract infections by different medical practices, including homeopathy, and consumption of antibiotics in primary care: The EPI3 cohort study in france 2007-2008, PLoS ONE. 9 (2014). doi:10.1371/journal.pone.0089990.

[8] L.R. Milgrom, "Living is easy with eyes closed ..." on blinded RCTs and specific and non-specific effects of complex therapeutic interventions, Eur. J. Integr. Med. 6 (2014) 552-559. doi:10.1016/j.eujim.2014.06.008.

[9] P. Bellavite, Complexity science and homeopathy: a synthetic overview, Homeopathy. 92 (n.d.) 203-212. doi:10.1016/j.homp.2003.08.002.

[10] I.R. Bell, G.E. Schwartz, Adaptive network nanomedicine: an integrated model for homeopathic medicine, Front. Biosci. Sch. Ed. 5 (2013) 685-708.

[11] J. Kleijnen, P. Knipschild, G. ter Riet, Clinical trials of homoeopathy., Bmj. 302 (1991) 316-323.

[12] K. Linde, N. Clausius, G. Ramirez, D. Melchart, F. Eitel, L.V. Hedges, W.B. Jonas, Are the clinical effects of homoeopathy placebo effects? A meta-analysis of placebo-controlled trials, The Lancet. 350 (1997) 834-843. doi:10.1016/S0140-6736(97)02293-9.

[13] K. Linde, M. Scholz, G. Ramirez, N. Clausius, D. Melchart, W.B. Jonas, Impact of study quality on outcome in placebo-controlled trials of homeopathy, J. Clin. Epidemiol. 52 (1999) 631-636.

[14] M. Cucherat, M.C. Haugh, M. Gooch, J.P. Boissel, Evidence of clinical efficacy of homeopathy. A meta-analysis of clinical trials. HMRAG. Homeopathic Medicines Research Advisory Group, Eur. J. Clin. Pharmacol. 56 (2000) 27-33.

[15] A. Shang, K. Huwiler-Müntener, L. Nartey, P. Jüni, S. Dörig, J.A. Sterne, D. Pewsner, M. Egger, Are the clinical effects of homoeopathy placebo effects? Comparative study of placebocontrolled trials of homoeopathy and allopathy, The Lancet. 366 (2005) 726-732.

[16] R.T. Mathie, S.M. Lloyd, L.A. Legg, J. Clausen, S. Moss, J.R. Davidson, I. Ford, Randomised placebo-controlled trials of individualised homeopathic treatment: systematic review and meta-analysis, Syst. Rev. 3 (2014). doi:10.1186/2046-4053-3-142.

[17] M. Castro, Homeopathy. A theoretical framework and clinical application, J. Nurse. Midwifery. 44 (1999) 280-290.

[18] A. Chitty, Review of evidence, New Dig. (2009) 20-26.

[19] M. Mitchell, J. Williams, E. Hobbs, K. Pollard, The use of complementary therapies in maternity services: A survey., Br. J. Midwifery. 14 (2006).

[20] J. Adams, C.-W. Lui, D. Sibbritt, A. Broom, J. Wardle, C. Homer, S. Beck, Women's use of complementary and alternative medicine during pregnancy: A critical review of the literature, Birth. 36 (2009) 237-245. doi:10.1111/j.1523-536X.2009.00328.x. 
[21] C. Vrielinck, D. Lanssens, J. Goossens, I. Tency, Complementaire en Alternatieve Therapieën (CAT), Tijdschr. Voor Vroedvrouwen. 23 (2017) 144-155.

[22] A. Andonegui, F. Sánchez, M. Quintana, M. Aguiar, I. Orbe, A. Fariñas, L. Barbero, I. Lete, Homoeopathy during pregnancy: A critical appraisal, Prog. Obstet. Ginecol. 60 (2017) 82-87.

[23] J. Frawley, D. Sibbritt, A. Broom, C. Gallois, A. Steel, J. Adams, Women's attitudes towards the use of complementary and alternative medicine products during pregnancy, J. Obstet. Gynaecol. 36 (2016) 462-467. doi:10.3109/01443615.2015.1072804.

[24] M. Kalder, K. Knoblauch, I. Hrgovic, K. Münstedt, Use of complementary and alternative medicine during pregnancy and delivery, Arch. Gynecol. Obstet. 283 (2011) 475-482. doi:10.1007/s00404-010-1388-2.

[25] J.L. Bishop, K. Northstone, J.R. Green, E.A. Thompson, The use of Complementary and Alternative Medicine in pregnancy: Data from the Avon Longitudinal Study of Parents and Children (ALSPAC), Complement. Ther. Med. 19 (2011) 303-310. doi:10.1016/j.ctim.2011.08.005.

[26] D.M. Mitchell, Women's use of complementary and alternative medicine in pregnancy: Narratives of transformation, Complement. Ther. Clin. Pract. 23 (2016) 88-93. doi:10.1016/j.ctcp.2015.05.006.

[27] D. Stewart, A. Pallivalappila, A. Shetty, B. Pande, J. McLay, Healthcare professional views and experiences of complementary and alternative therapies in obstetric practice in North East Scotland: a prospective questionnaire survey, BJOG Int. J. Obstet. Gynaecol. 121 (2014) 10151019.

[28] H.G. Hall, L.G. McKenna, D.L. Griffiths, Midwives' support for Complementary and Alternative Medicine: A literature review, Women Birth. 25 (2012) 4-12. doi:10.1016/j.wombi.2010.12.005.

[29] H.G. Hall, D.L. Griffiths, L.G. McKenna, Complementary and alternative medicine in midwifery practice: Managing the conflicts, Complement. Ther. Clin. Pract. 18 (2012) 246-251. doi:10.1016/j.ctcp.2012.06.010.

[30] M. Castro, Homeopathy for pregnancy, birth, and your baby's first year, 1st U.S. ed, St. Martin's Press, New York, 1993.

[31] R. Ijsseldijk, P. ljsseldijk, Klassieke Homeopathie voor Zwangerschap Bevalling en Baby, Lutra services bv, Eindhoven, 2013.

[32] L. Lalor, Fertility Success Using Homeopathy and the Vannier Method, Homoeopath. Links. 18 (2005) 9-12.

[33] T. Kalampokas, S. Botis, A. Kedikgianni-Antoniou, D. Papamethodiou, S. Kivellos, V. Papadimitriou, G. Salvanos, N. Paparistidis, I. Gavaris, C. Sofoudis, E. Kalampokas, G. Farmakides, G. Vithoulkas, Homeopathy for infertility treatment: a case series, Clin. Exp. Obstet. Gynecol. 41 (2014) 158-159.

[34] M. Oberbaum, N. Galoyan, L. Lerner-Geva, S.R. Singer, S. Grisaru, D. Shashar, A. Samueloff, The effect of the homeopathic remedies Arnica montana and Bellis perennis on mild postpartum bleeding - A randomized, double-blind, placebo-controlled study - Preliminary results, Complement. Ther. Med. 13 (2005) 87-90. doi:10.1016/j.ctim.2005.03.006.

[35] D. Gregg, Birth herbs and homeopathics: stats and stories., Midwifery Today. (2006) 34-36 3p.

[36] B. Cummings, Empowering women: Homoeopathy in midwifery practice, Complement. Ther. Nurs. Midwifery. 4 (1998) 13-16. doi:10.1016/S1353-6117(98)80007-3.

[37] J.E. Duckworth, Straddling paradigms: an interpretive hermeneutic exploration of the experience of midwives practising homeopathy, 2015. uk.bl.ethos.656980.

[38] H.G. Hall, L.G. McKenna, D.L. Griffiths, Contextual factors that mediate midwives' behaviour towards pregnant women's use of complementary and alternative medicine, Spec. Issue Public Heal. Serv. Res. Integr. Med. 5 (2013) 68-74. doi:10.1016/j.eujim.2012.09.002.

[39] D. Tiran, Complementary therapies education in midwifery, Complement. Ther. Nurs. Midwifery. 1 (1995) 41-43. doi:10.1016/S1353-6117(05)80033-2. 
[40] S. Cant, P. Watts, A. Ruston, The rise and fall of complementary medicine in National Health Service hospitals in England, Complement. Ther. Clin. Pract. 18 (2012) 135-139. doi:10.1016/j.ctcp.2012.05.004.

[41] D. Tiran, Complementary therapies in pregnancy: Midwives' and obstetricians' appreciation of risk, Complement. Ther. Clin. Pract. 12 (2006) 126-131. doi:10.1016/j.ctcp.2005.10.003.

[42] Fundamenten van de homeopathie en module verloskunde vroedvrouw - CEDH - Antwerpen | Vroedvrouwen.be - VBOV, (n.d.). http://www.vroedvrouwen.be/nl/activiteit/fundamentenvan-de-homeopathie-en-module-verloskunde-vroedvrouw-cedh-antwerpen (accessed November 14, 2017).

[43] Moniteur Belge - Belgisch Staatsblad, (n.d.). http://www.ejustice.just.fgov.be/cgi/article_body.pl?language=nl\&caller=summary\&pub_date $=2014-05-12 \&$ numac $=2014024146$ (accessed January 19, 2018).

[44] M. Steen, J. Calvert, Self-administered homeopathy part two: A follow-up study, Br. J. Midwifery. 15 (2007) 359-365.

[45] K. Lonka, S. Lindblom-Ylanne, Epistemologies, conceptions of learning, and study practices in medicine and psychology, High. Educ. 31 (1996) 5-24. doi:10.1007/BF00129105.

[46] J. Mezirow, Transformative Learning: Theory to Practice, New Dir. Adult Contin. Educ. 1997 (1997) 5-12. doi:10.1002/ace.7401.

[47] D.A. Kolb, Experiential learning: experience as the source of learning and development, Prentice-Hall, 1984.

[48] G. Armstrong, L. Headrick, W. Madigosky, G. Ogrinc, Designing Education to Improve Care, Jt. Comm. J. Qual. Patient Saf. 38 (2012) 5-14.

[49] K.P. Cross, Adults as learners, Jossey-Bass, 1981.

[50] H.A. Roberts, The study of remedies by comparison, B Jain, New Delhi, 1995.

[51] D. Gijbels, M. Segers, E. Struyf, Constructivist learning environments and the (im)possibility to change students' perceptions of assessment demands and approaches to learning, Instr. Sci. 36 (2008) 431-443. doi:10.1007/s11251-008-9064-7.

[52] J. Biggs, The Role of Metacognition in Enhancing Learning, Aust. J. Educ. 32 (1988) 127-138. doi:10.1177/000494418803200201.

[53] M. Vaismoradi, H. Turunen, T. Bondas, Content analysis and thematic analysis: Implications for conducting a qualitative descriptive study: Qualitative descriptive study, Nurs. Health Sci. 15 (2013) 398-405. doi:10.1111/nhs.12048.

[54] H.F. Hsieh, S. Shannon, Three approaches to qualitative content analysis, Qual. Health Res. 15 (2005). doi:10.1177/1049732305276687.

[55] N.K. Gale, G. Heath, E. Cameron, S. Rashid, S. Redwood, Using the framework method for the analysis of qualitative data in multi-disciplinary health research, BMC Med. Res. Methodol. 13 (2013) 117. doi:10.1186/1471-2288-13-117.

[56] Koninklijke Academie voor Geneeskunde van België, Ethische code wetenschappelijk onderzoek, (2008).

[57] P. Viksveen, A. Steinsbekk, Undergraduate homeopathy education in Europe and the influence of accreditation, Homeopathy. 100 (2011) 253-258. doi:10.1016/j.homp.2011.06.006.

[58] A. Bryman, Integrating quantitative and qualitative research: how is it done?, Qual. Res. 6 (2006) 97-113.

[59] M.Q. Patton, The Sociological Roots of Utilization-Focused Evaluation, Am. Sociol. 46 (2015) 457-462. doi:10.1007/s12108-015-9275-8.

[60] Vereniging Verloskunde \& Homeopathie, (n.d.). http://vvenh.nl/opleiding/ (accessed January 15, 2018).

[61] Dr. Micha Bitschnau | Ausbildungszentrum, (n.d.). http://www.homoeopathin.at/ausbildungszentrum.html (accessed January 17, 2018). 


\section{List of Tables}

Table 1 Demographic Characteristics of the participants (gender, age and years of experience), $n=8 . .9$ Table 2 Evaluation of the course content; $n=8$. . . .

Table 3 Evaluation of the content of the course; $n=8$; eliciting main themes ...................................... 10

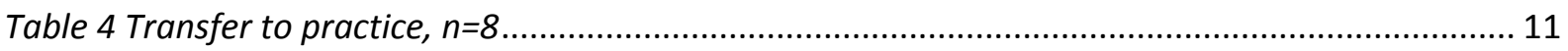

Table 5 Evaluation of usefulness of the course; $n=8$; eliciting main themes ....................................... 11

Table 6 Evaluation of delivery of the course; $n=8$; eliciting main themes ............................................ 12

Table 7 Recommendation for future course; $n=8$; eliciting main themes ......................................... 13

Table 8 Framework containing raw data of participants' comments ( $n=8)$ : Columns for Topics and Rows for Participants 


\section{Appendix A: Questionnaire Evaluation}

\section{Homeopathy in Obstetric Practice}

This form inquires about your experience of the sessions 'Homeopathy in Obstetric Practice' given by the CKH in collaboration with the Thomas More Hogeschool

\section{EVALUATION OF THE CONTENT OF THE COURSE}

Did you find the material interesting? Did it fulfil your expectations?

In general, how do you evaluate the content of the course?

Not interesting 12345 Very interesting

Day 1: Homeopathy: translate a holistic vision on health and disease to the obstetric practice How do you evaluate the content of this session?

Not interesting 12345 Very interesting

Day 2: Homeopathy: introduction in materia medica and sources, example of how to study a remedy picture, cases How do you evaluate the content of this session?

Not interesting 12345 Very interesting

Day 3: Homeopathy: case taking, posology, reaction patterns, case management How do you evaluate the content of this session? Not interesting 12345 Very interesting

Day 4: Homeopathic support during pregnancy. Remedy pictures and cases

How do you evaluate the content of this session?

Not interesting 12345 Very interesting

Day 5: Homeopathic support during labour.

How do you evaluate the content of this session?

Not interesting 12345 Very interesting

Day 6: Homeopathic support during breastfeeding and the first stage of life How do you evaluate the content of this session Not interesting 12345 Very interesting

\section{Comments}

Can you describe in more details which items you found most or least interesting? Which items/subjects/remedies did you find missing?

\section{TRANSFER TO PRACTICE}

Did you find the material useful for your obstetric practice?

Do you think you will use it in your practice in the near future?

Day 1: Homeopathy: translate a holistic vision on health and disease to the obstetric practice Not useful in practice 12345 Very useful in practice

Day 2: Homeopathy: introduction in materia medica and sources, example of how to study a remedy picture, cases Not useful in practice 12345 Very useful in practice

Day 3: Homeopathy: case taking, posology, reaction patterns, case management Not useful in practice 12345 Very useful in practice 
Day 4: Homeopathic supporting during pregnancy. Remedy pictures and cases

Not useful in practice 12345 Very useful in practice

Day 5: Homeopathic supporting during labour.

Not useful in practice 12345 Very useful in practice

Day 6: Homeopathic supporting during breastfeeding and the first stage of life

Not useful in practice 12345 Very useful in practice

\section{Comments}

Is this course sufficient to work as a midwife-homeopath?

If not, what more do you wish for?

\section{DIDACTICS}

How do you evaluate the way the material was delivered? You can write your comments for each session in the space below.

Day 1: Homeopathy: translate a holistic vision on health and disease to the obstetric practice - Hilde Vanthuyne

Day 2: Homeopathy: introduction in materia medica and sources, example of how to study a remedy picture, cases - Wim Serneels and Herlinde Bral

Day 3: Homeopathy: case taking, posology, reaction patterns, case management - Anne Vervarcke

Day 4: Homeopathic supporting during pregnancy. Remedy pictures and cases - Goedele De Nolf

Day 5: Homeopathic supporting during labour. - Miriam Lenz

Day 6: Homeopathic supporting during breastfeeding and the first stage of life - Hilde Vanthuyne

\section{RECOMMENDATIONS FOR THE FUTURE}

How do you envision an ideal training in homeopathy in obstetrics? Write your recommendations for the future in the space below. Which aspects of the course would you keep? Improve? Dismiss?

Write in the space below what you would consider the ideal way (content, timeframe...) of the training to be able to use homeopathy in your obstetric practice. Don't take into account any financial or practical barrier but think of the realistic training need. 


\section{Appendix B: Framework for content analysis}

Table 8 Framework containing raw data of participants' comments ( $n=8$ ): Columns for Topics and Rows for Participants

\begin{tabular}{|c|c|c|c|c|c|}
\hline $\begin{array}{l}\text { Respondent } \\
\text { (anonymous) }\end{array}$ & $\begin{array}{l}\text { Content } \\
\text { What topics did you find } \\
\text { most/least interesting? }\end{array}$ & $\begin{array}{l}\text { Content } \\
\text { What items did you miss }\end{array}$ & $\begin{array}{l}\text { Transfer } \\
\text { Does the course give } \\
\text { sufficient ground to work } \\
\text { with it in practice }\end{array}$ & $\begin{array}{l}\text { Recommendations } \\
\text { What part of the course } \\
\text { would you keep, improve, } \\
\text { omit }\end{array}$ & $\begin{array}{l}\text { Recommendations } \\
\text { How would an ideal } \\
\text { course look like }\end{array}$ \\
\hline$A$ & $\begin{array}{l}\text { Most interesting: } \\
\text { Vision, how symptoms of } \\
\text { the pregnant woman can } \\
\text { lead to a remedy for the } \\
\text { child, cases, anamnesis }\end{array}$ & & $\begin{array}{l}\text { Insufficient; did not } \\
\text { follow everything; need } \\
\text { for more practice; bring } \\
\text { cases from our own } \\
\text { practice and analyse } \\
\text { them in group }\end{array}$ & $\begin{array}{l}\text { Keep everything; insight } \\
\text { in homeopathic vision; } \\
\text { cases }\end{array}$ & $\begin{array}{l}\text { Sufficient background } \\
\text { and knowledge to be able } \\
\text { to find a remedy quickly } \\
\text { For those interested: } \\
\text { supplementary time to } \\
\text { take an anamnesis during } \\
\text { pregnancy to find a } \\
\text { remedy }\end{array}$ \\
\hline$B$ & $\begin{array}{l}\text { Excellent with regard to } \\
\text { the circumstances: so } \\
\text { much information in so } \\
\text { little time }\end{array}$ & $\begin{array}{l}\text { Learn to use the } \\
\text { repertory } \\
\text { How to interpret the } \\
\text { information correctly for } \\
\text { homeopathic ends } \\
\text { How to take a good } \\
\text { anamnesis }\end{array}$ & Absolutely not. & $\begin{array}{l}\text { More explanation about } \\
\text { the repertory }\end{array}$ & $\begin{array}{l}\text { Sufficient knowledge to } \\
\text { take a } 2 \text { hours } \\
\text { consultation }\end{array}$ \\
\hline C & $\begin{array}{l}\text { For my line of work } \\
\text { support during } \\
\text { breastfeeding was the } \\
\text { most interesting topic }\end{array}$ & $\begin{array}{l}\text { Postpartum could have } \\
\text { been more expanded }\end{array}$ & $\begin{array}{l}\text { I have got the feeling that } \\
\text { I cannot yet start } \\
\text { working. It is all so } \\
\text { overwhelming and I need } \\
\text { more time to process and } \\
\text { study. }\end{array}$ & $\begin{array}{l}\text { Everything was very } \\
\text { good. More cases } \\
\text { perhaps? }\end{array}$ & $?$ \\
\hline $\mathrm{D}$ & $\begin{array}{l}\text { Most interesting: cases, } \\
\text { materia medica, links } \\
\text { with the periodic table, } \\
\text { thinking in groups (for } \\
\text { instance plants) }\end{array}$ & $\begin{array}{l}\text { Learning from our own } \\
\text { cases, looking for the red } \\
\text { thread } \\
\text { Improving anamnesis } \\
\text { techniques }\end{array}$ & $\begin{array}{l}\text { This is an introduction. I } \\
\text { will not call myself a } \\
\text { homeopath-midwife after } \\
\text { this course. }\end{array}$ & $\begin{array}{l}\text { Everything is OK but } \\
\text { insufficient to call } \\
\text { yourself a homeopath }\end{array}$ & $\begin{array}{l}\text { The complete training is } \\
\text { needed to be able to } \\
\text { provide a decent } \\
\text { treatment, or more } \\
\text { training for the acute }\end{array}$ \\
\hline
\end{tabular}




\begin{tabular}{|c|c|c|c|c|c|}
\hline & & & & & $\begin{array}{l}\text { picture of an acute } \\
\text { obstetric situation } \\
\text { More repertorising and } \\
\text { more materia medica }\end{array}$ \\
\hline $\mathrm{E}$ & & & $\begin{array}{l}\text { No, a lot more self- } \\
\text { learning is required. } \\
\text { Regular return days. }\end{array}$ & & Online course with coach. \\
\hline $\mathrm{F}$ & $\begin{array}{l}\text { The whole was well } \\
\text { constructed (basis and } \\
\text { practice). Day } 2 \text { was often } \\
\text { a repetition }\end{array}$ & $\begin{array}{l}\text { Materia medica could } \\
\text { have been more } \\
\text { explained in concrete in } \\
\text { the sessions. With the } \\
\text { course evolving you felt it } \\
\text { was insufficient to } \\
\text { function as a midwife- } \\
\text { homeopath. }\end{array}$ & $\begin{array}{l}\text { No, this is just the tip of } \\
\text { the iceberg. A full } \\
\text { education is needed. }\end{array}$ & $\begin{array}{l}\text { First of all keep } \\
\text { everything and widen. } \\
\text { Work more specifically } \\
\text { from cases and teach } \\
\text { remedies after basic } \\
\text { introduction. }\end{array}$ & $\begin{array}{l}\text { The 'Classical } \\
\text { Homeopath' program } \\
\text { adapted to midwifery. }\end{array}$ \\
\hline G & $\begin{array}{l}\text { For me it was well } \\
\text { constructed. Sometimes I } \\
\text { felt a bit overwhelmed } \\
\text { and I could not give a } \\
\text { place to everything, } \\
\text { which made it difficult. }\end{array}$ & $\begin{array}{l}\text { For me it is too short; I } \\
\text { am still 'hungry'. }\end{array}$ & $\begin{array}{l}\text { It is completely in my line } \\
\text { of thought; this is quite } \\
\text { nice as a confirmation of } \\
\text { all that I felt already. But } \\
\text { way too short to practice. }\end{array}$ & $\begin{array}{l}\text { Not omit anything! But if } \\
\text { possible, augment. }\end{array}$ & $\begin{array}{l}\text { I am not sure if it is at all } \\
\text { possible to practice after } \\
\text { such a short cycle of } \\
\text { sessions? I am still in } \\
\text { doubt how I shall go on } \\
\text { from here. }\end{array}$ \\
\hline $\mathrm{H}$ & $\begin{array}{l}\text { All items were extremely } \\
\text { interesting. I want more! I } \\
\text { am a fan! }\end{array}$ & $\begin{array}{l}\text { Not enough days and } \\
\text { hours to be able to } \\
\text { proceed with the material } \\
\text { necessary. }\end{array}$ & $\begin{array}{l}\text { No, not for me. I need } \\
\text { more information, } \\
\text { background and training. }\end{array}$ & $\begin{array}{l}\text { Keep everything but } \\
\text { expand it all - maybe a } 1 \\
\text { year training instead of } 6 \\
\text { months to allow more } \\
\text { time for growing into it. }\end{array}$ & $\begin{array}{l}\text { Instead of broadly more } \\
\text { deeply } \\
\text { More information on } \\
\text { materia medica: more } \\
\text { practical information }\end{array}$ \\
\hline
\end{tabular}




\begin{tabular}{|c|c|c|c|c|c|c|}
\hline \multirow{2}{*}{$\begin{array}{l}\text { Respondent } \\
\text { (anonymous) }\end{array}$} & \multicolumn{6}{|c|}{ Evaluation of the way the course was delivered } \\
\hline & Philosophy & Theory & Anamnesis & Pregnancy & Labour & Breastfeeding \\
\hline A & & & $\begin{array}{l}\text { Well delivered, } \\
\text { interesting, good } \\
\text { provides insight in } \\
\text { homeopathic work }\end{array}$ & & & \\
\hline B & $\mathrm{OK}$ & Reasonable & Excellent & Excellent & Perfect & $\mathrm{OK}$ \\
\hline $\mathrm{C}$ & Very interesting & Very good & Interesting & Interesting & Very good & Very interesting \\
\hline $\mathrm{D}$ & $\begin{array}{l}\text { Clearly delivered } \\
\text { but the material } \\
\text { was familiar. }\end{array}$ & $\begin{array}{l}\text { Input of therapist } \\
\text { was +value }\end{array}$ & Asks for more & $\begin{array}{l}\text { Good introduction but } \\
\text { asks for more }\end{array}$ & $\begin{array}{l}\text { Very interesting but } \\
\text { need time to get } \\
\text { acquainted with the } \\
\text { remedies. Excellent } \\
\text { teaching }\end{array}$ & OK \\
\hline $\mathrm{E}$ & $\mathrm{OK}$ & OK & $\mathrm{OK}$ & Least practical & Very good & OK \\
\hline $\mathrm{F}$ & $\begin{array}{l}\text { Nice introduction } \\
\text { in basic principles. } \\
\text { Well explained }\end{array}$ & $\begin{array}{l}\text { Repetition of day } 1 . \\
\text { Materia medica } \\
\text { could have been } \\
\text { more }\end{array}$ & $\begin{array}{l}\text { Other beautiful } \\
\text { introduction }\end{array}$ & $\begin{array}{l}\text { Nice content. Structure } \\
\text { could have been better } \\
\text { if MM would have been } \\
\text { discussed before case } \\
\text { instead of afterwards }\end{array}$ & $\begin{array}{l}\text { Good practical info, } \\
\text { missed cases to } \\
\text { discuss MM }\end{array}$ & $\begin{array}{l}\text { Good structure, } \\
\text { started with own } \\
\text { cases which was nice, } \\
\text { discussed remedies in } \\
\text { practice }\end{array}$ \\
\hline G & $\begin{array}{l}\text { Beautiful } \\
\text { introduction and } \\
\text { nice start of the } \\
\text { course. Well } \\
\text { delivered }\end{array}$ & $\begin{array}{l}\text { My memory of this } \\
\text { day is a bit more } \\
\text { confused but a full } \\
\text { and satisfied feeling } \\
\text { after the lecture }\end{array}$ & $\begin{array}{l}\text { I remember this as a } \\
\text { steam train and } \\
\text { asked for some time } \\
\text { to process but } \\
\text { certainly OK }\end{array}$ & $\begin{array}{l}\text { Nice day! 'First' practical } \\
\text { use. Very attractive but } \\
\text { also concern: how can I } \\
\text { apply this in practice. }\end{array}$ & $\begin{array}{l}\text { Super. Very lived } \\
\text { and useful in } \\
\text { practice. }\end{array}$ & $\begin{array}{l}\text { Nice exercise, } \\
\text { confronting, good } \\
\text { keys to work with } \\
\text { later }\end{array}$ \\
\hline $\mathrm{H}$ & $\begin{array}{l}\text { Clear info about } \\
\text { what homeopathy } \\
\text { actually is }\end{array}$ & $\begin{array}{l}\text { Clear info about the } \\
\text { Organon; maybe a } \\
\text { bit less stories but } \\
\text { more case histories }\end{array}$ & $\begin{array}{l}\text { Excellent } \\
\text { information, useful }\end{array}$ & Very useful information & $\begin{array}{l}\text { Applicable in } \\
\text { practice, good } \\
\text { examples }\end{array}$ & $\begin{array}{l}\text { Fun to pick out own } \\
\text { cases and find } \\
\text { answers there. }\end{array}$ \\
\hline $\mathrm{H}$, addition & \multicolumn{6}{|c|}{ Beautiful, emotional information. True reality. Very beautiful cases! Thank you for being so vulnerable! } \\
\hline
\end{tabular}




\section{Appendix C: Glossary}

Materia medica

Repertory

Repertorisation

Classical homeopathy

Practical homeopathy

Complex homeopathy

Clinical homeopathy
Body of collected knowledge of the therapeutic properties of any substance used for healing; description of the homeopathic remedy pictures

Systemic cross reference of symptoms and disorders to the homeopathic medicine

Technique of using a repertory to identify the homeopathic medicines whose materia medica corresponds most closely to the clinical picture of the patient

Approach according the principles described in the earlier versions of the Organon; mainly coming down to administering one dose of a single remedy at a time

In practical homeopathy any therapeutic approach may be used that is considered appropriate to the case, including detox, supplements, flower remedies...

Using complex remedies, i.e. a mixture of homeopathic remedies in the one bottle, for minor or acute problems

Clinical homeopathy uses specific remedies (often complexes) that target particular disease(s), $\operatorname{organ}(\mathrm{s})$, or tissue(s) and match with the symptoms or complaints of the individual.

Word Count: Abstract: 240; Article: 6037 (References and appendices excluded) 